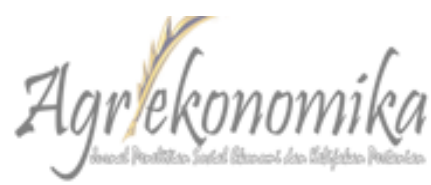

Jurnal Sosial Ekonomi dan Kebijakan Pertanian

http://journal.trunojoyo.ac.id/agriekonomika

Agriekonomika Volume 8, Nomor 1, 2019

\title{
Leading Commodities of Food Crops and Plantation Subsector in Pinrang District
}

\author{
St. Aisyah Ramli and Sitti Khadijah Yahya Hiola \\ Faculty of Agriculture, Muhammadiyah University of Makassar, Indonesia \\ Received: February 2019; Accepted: April 2019; Published: April 2019 \\ DOI: http://doi.org/10.21107/agriekonomika.v8i1.4999
}

\begin{abstract}
This study aims to determine the food crop and plantation subsectors which are the leading subsectors in Pinrang District. The determination analyzed using the Location Quotient method which produces commodities classified as a base or non-base commodities which can contribute to increasing farmer income and regional income. The data sources used are primary data from interviews with farmers while secondary data on food crop and plantation production in Pinrang District for five years (2013-2017) were obtained from the Agriculture Service and BPS of Pinrang District. The results show thatthe food crop subsector is a base commodity and is very potential, namely wetland paddy and maize which have a base area in five sub-districts in Pinrang District. Whereas in the plantation sub-sector which is the basis, namely coconut, coffee, and cocoa, although the highest $L Q$ value is in coffee commodities in Lembang subdistrict. Thus, commodities in the food crops and plantation sub-sectors are basic commodities that are worth developing. Pinrang District is one of the rice barns in South Sulawesi, which holds the position of Pinrang District as a potential producer of food crops. In addition to wetland paddy, other food crops produced are maize and beans. The most dominant plantation crops in Pinrang District are coconut, coffee, and cocoa, which are excellent crops.
\end{abstract}

Keywords: Food Crops, Plantations, Commodity Base

\section{INTRODUCTION}

The agricultural sector includes food crops, horticulture, plantations, fisheries, livestock, and forestry. Agriculture is one of the most dominant sectors in people's income in Indonesia because the work of the majority of the population is farmers (Sukirno, 2004). Competitive advantages of a region, regional specialization, and agricultural potential possessed by the region basically affect the growth economy region. Thus, the main priority to be explored and developed in carrying out agricultural development as a whole with the utilization and development region.
In each district must optimize the potential of resources with the leading sectors that exist in the region to realize economic development in the area. South Sulawesi's Central Bureau of Statistics noted that Pinrang District is one of the regions that have good economic growth in South Sulawesi. Sectorally, the economic prospects of Pinrang District are issued by the primary economic sector, namely the agriculture-plantation sector which is the economic source of the community. Pinrang District's Gross Regional Domestic Product (GRDP) on the basis of current prices in 2011-2014 (million rupiah), namely

Cite this as:

Ramli, St. A., \& Hiola, S. K. (2019). Leading Commodities of Food Crops and Plantation Subsector in Pinrang District. Agriekonomika, 8(1). 7-13. http://doi.org/10.21107/agriekonomika.v8i1.4999

\footnotetext{
Corresponding author:

Address : Jl. Sultan Alauddin No. 259 Makassar

Email : :st.aisyah@unismuh.ac.id

Phone : :085396555707
} 
7.549.544,01 (2011), 8.738.253,10 (2012), 9.847.320,93 (2013) and 11.358.262,74 (2014) (Pinrang District Central Bureau of Statistics, 2015). Various types of food crops and plantations were also developed in Pinrang District, but none of them have been made as superior commodities in the area. Therefore, this study aims to determine which food commodities and superior plantations are suitable to be developed in Pinrang District so that efforts are made to produce commodities that can produce food icons in the area.

Based on previous research that analyzes the potential of superior commodities in various sectors in rural and urban areas, sectors that have a proportionate positive growth component value, namely agriculture, building and construction, trade, hotels and restaurants, transportation and communication, and services. While sectors that have a proportional negative growth component value, namely the mining sector, the industrial processing, and other banks and financial institutions. Supporting factors and obstacles to the development of superior commodities are divided into four indicators, namely input indicators, production processes, outputs, and government roles (Wicaksono, 2011; Mangilaleng, et al, 2015; Masniadi, et al, 2012; Amalia, 2012; Rasyid, 2016; Hayati, et al, 2017; Novita, et al, 2014; Harinta, et al, 2018; Hayati and Nugroho, 2018; Watemin and Putri, 2016; Sapriadi and Hasbiullah, 2015).

According to Arsyad (2005); Sjafrizal (2008), the economic basis is the main goal in economic growth in a region. Industrial production or growth processes in regions that use local resources increase labor, materials, and exports generate economic growth or regional wealth, increasing per capita income and create employment opportunities in the area. According to Ratag, et al (2016), that data on Gross Regional Domestic Product (GRDP) was used to look at regional economic growth and the success of regional development. In addition, production data can also use as information about the results of development and can be used to determine development policies in a region.

\section{METHOD}

The location of this study is in Pinrang District, with the consideration that the GRDP contributes to the agricultural sector, especially food crops and plantations (Pinrang District in figures, 2013-2017). This study uses both primary and secondary data.Primary data used in this study include data from interviews with groups of farmers who grow food crops and plantations to support secondary data taken. Secondary data used were 5-year time series data from Pinrang District from 2013-2017. The data was obtained from the Central Statistics Agency of Pinrang District.

According to Azis, et al (2015), the method of Location Quotient Analysis (LQ) aims to identify a commodity that exists in a region whether it is included in a base or non-base. Determination of superior commodities of food crops and plantations in Pinrang District by checking commodity production documents from the Central Statistics Agency produced in each sub-district in Pinrang District and then analyzed using the Location Quotient (LQ) method with Microsoft Excel 2010 analysis tool, written with the formula:

$L Q=\frac{v i / v t}{\mathrm{Vi} / \mathrm{vt}}$

LQ is Location Quotients from food crops and plantation subsectors in Pinrang District, $\mathbf{v i}$ is value of production from the food crops and plantation subsector in the Pinrang District area, vt is the total production value of the food crop and plantation subsector of Pinrang District, Vi is the value of production from the food crops and plantation subsector in the South Sulawesi Province, Vt is the total production value of the food crops and plantation subsector of the South Sulawesi Province 
The criteria for using $L Q$ are as follows:

1. If $L Q>1$, the commodity is classified as the base sector

2. If $L Q<1$, the commodity is classified as non-base sector and

3. If $L Q=1$, shows the production of commodities for the needs of the region itself and cannot afford to be sold outside the region.

\section{RESULTS AND DISCUSSION}

The development of food crops and plantations in Pinrang District 2017 can be seen in Table 1.

Based on Table 1, the types of food crops that are mostly produced in Pinrang District include Wetland Paddy, maize, peanuts, soybeans, and green beans. While many types of plantation crops are produced, namely coconut, cocoa, and coffee. Duampanua subdistrict has a greater harvest area than other subdistricts for Wetland Paddy commodities, Batulappa sub-district has a larger harvest area for maize commodities. While the harvest area for peanuts, green beans and soybeans are only in a few regions. Then, Mattiro Bulu, Patampanua and Lembang Subdistricts have a large harvest area for coconut commodities. The climbing sub-district has the largest coffee and cocoa harvest area.

This study used the LQ method to analyze the leading commodities in each sub-district in Pinrang District. Data were taken from BPS of Pinrang District as many as twelve sub-districts fulfilling the minimum requirements for data usage for LQ analysis, namely time series data for five years (2013-2017). The food crops commodities studied were wetland paddy, maize, peanuts, soybeans, and green beans. While the plantation commodities studied were coconut, coffee, and cocoa. The results show that, the commodities of the food crop and plantation sub-sectors can be identified in Pinrang District which is a base and non-base sector. The results of calculation of Location Quotient (LQ) based on food crops can be seen in Table 2.

Table 2, shows that the results of LQ analysis in Pinrang District, namely the commodity of Wetland Paddy, maize, peanuts, soybeans, and green beans are included in the base commodity as indicated by the $L Q$ value of more than

Table 1

The Area of Food Crops and Plantations in Pinrang, 2017

\begin{tabular}{|c|c|c|c|c|c|c|c|c|c|c|c|}
\hline \multirow[b]{2}{*}{ No } & \multirow[b]{2}{*}{ Subdistrict } & \multicolumn{10}{|c|}{ Harvest area(Ha) } \\
\hline & & $\begin{array}{l}\text { Wetland } \\
\text { Paddy }\end{array}$ & Maize & $\begin{array}{l}\text { Pea- } \\
\text { nuts }\end{array}$ & $\begin{array}{l}\text { Soya- } \\
\text { beans }\end{array}$ & $\begin{array}{l}\text { Green } \\
\text { Beans }\end{array}$ & $\begin{array}{l}\text { Hybrid } \\
\text { Coconut }\end{array}$ & $\begin{array}{l}\text { Coconut } \\
\text { Deep }\end{array}$ & $\begin{array}{c}\text { Robusta } \\
\text { Coffe }\end{array}$ & $\begin{array}{c}\text { Arabica } \\
\text { Coffe }\end{array}$ & Cocoa \\
\hline 1 & Suppa & 2.022 & 584 & 1 & - & - & 64 & 822 & - & - & 107 \\
\hline 2 & $\begin{array}{l}\text { Mattiro } \\
\text { Sompe }\end{array}$ & 9.646 & 166 & - & - & - & 101 & 313 & - & - & 192 \\
\hline 3 & Lanrisang & 8.547 & 1.143 & 1 & - & - & 83 & 525 & - & - & 545 \\
\hline 4 & Mattiro Bulu & 11.979 & 943 & 10 & - & - & 280 & $1.124,5$ & - & - & 723,3 \\
\hline 5 & $\begin{array}{l}\text { Watang } \\
\text { Sawitto }\end{array}$ & 10.523 & 46 & - & - & - & - & 122,5 & - & - & 107,95 \\
\hline 6 & Paleteang & 5.070 & 173 & - & - & - & 88,5 & 893,3 & - & - & $1.066,22$ \\
\hline 7 & Tiroang & 11.271 & 271 & 2 & - & - & 14 & 604 & - & - & 1136 \\
\hline 8 & $\begin{array}{l}\text { Patam- } \\
\text { panua }\end{array}$ & 13.062 & 1.966 & 1 & - & - & 533 & $1.199,7$ & - & - & $2.064,7$ \\
\hline 9 & Cempa & 10.654 & 1.598 & - & - & - & 13 & 390 & - & - & 377 \\
\hline 10 & $\begin{array}{l}\text { Duam- } \\
\text { panua }\end{array}$ & 14.599 & 3.523 & 7 & - & 10 & 102 & 700 & 34 & - & 1.740 \\
\hline 11 & Batulappa & 3.276 & 5.279 & - & 25 & - & 3 & 373 & 51 & - & 3.840 \\
\hline 12 & Lembang & 5.552 & 5.102 & 18 & 70 & 19 & 83 & 1.615 & 3.729 & 493 & 7.797 \\
\hline
\end{tabular}

Source: Pinrang District Central Bureau of Statistics, 2017 
1 even though only a few districts. In the lowland rice commodities classified as bases, the value of $L Q>1$ is Mattiro bulu 1.14, Tiroang 1.08, Patampanua 1.27, Earthquake 1.04 and Duampanua 1.43. In the maize commodity belonging to the base, the region has $L Q>1$ namely Patampanua Subdistrict 1.33, Cempa 2.22, Duampanua 3, Batulappa 5.7 and Lembang 3.93. In the peanut commodity classified as the base region, it has $L Q>1$, namely Suppa 2.11 and Lembang 1.62. In the soybean commodity classified as the base region, it has $L Q>1$, namely Suppa subdistrict 1.69 , Batulappa 1.16 and Lembang 1.98. Finally, the green bean commodity belonging to the base region has $L Q>1$, namely Suppa subdistrict 1.39 and Lembang 1.29.

The maize commodity has the highest LQ of 5.70. The government supports the maize commodity because it has extensive adaptability and is suitable for use in paddy fields in the dry season. This is in accordance with Susilawati et al. (2016), that the commodities of rice, maize, and soybeans are superior commodities. Sweet potatoes, peanuts, and green beans are potential commodities
Pinrang District is also a development of paddy fields. LQ results are ranked number 1 along with maize commodities. This finding is supported by the development area of paddy fields in Pinrang District, covering an area of 33,420 ha, consisting of existing paddy fields covering an area of 31,680 ha and potential land for development covering 1,740 ha. Duampanua, Patampanua, Mattirobulu, Tiroang, and Cempa sub-districts are areas that increase rice productivity. This is in accordance with the results of Wicaksono's research (2011), that most sub-districts in Purworejo District in the agricultural sector and its sub-sectors are the base sectors and sub-sectors. The sub-districts that have the most sub-sectors are Bruno and Bener Sub-Districts. While the subsector which is the sub-sector of the base in most sub-districts in PurworejoDistrict is the food crops subsector.

Table 3, shows that base plantation commodities in Pinrang District are coconut, coffee, and cocoa. MattiroBulu, Paleteang, Patampanua, and Lembang subdistricts have $L Q$ values $>1$ in coconut commodities. Lembang subdistrict is a base sector area

Table 2

Results of Location Quontient (LQ) Commodity Base in Food Crops Sub-Sector in Subdistrict 2013-2017

\begin{tabular}{|c|c|c|c|c|c|c|}
\hline \multirow{2}{*}{ Number } & \multirow{2}{*}{ Sub-District } & \multicolumn{5}{|c|}{ Food Crop Subsector } \\
\hline & & Wetland Paddy & Maize & Peanuts & Soyabeans & Green Beans \\
\hline 1 & Suppa & 0,23 & 0,47 & 2,11 & 1,69 & 1,39 \\
\hline 2 & Mattiro Sompe & 0,99 & 0,13 & 0,04 & 0,00 & 0,08 \\
\hline 3 & Lanrisang & 0,80 & 0,85 & 0,38 & 0,00 & 0,10 \\
\hline 4 & Mattiro Bulu & 1,14 & 0,59 & 0,42 & 0,08 & 0,04 \\
\hline 5 & Watang Sawitto & 0,94 & 0,05 & 0,01 & 0,00 & 0,02 \\
\hline 6 & Paleteang & 0,50 & 0,12 & 0,00 & 0,00 & 0,00 \\
\hline 7 & Tiroang & 1,08 & 0,27 & 0,04 & 0,00 & 0,04 \\
\hline 8 & Patampanua & 1,27 & 1,33 & 0,03 & 0,49 & 0,00 \\
\hline 9 & Cempa & 1,04 & 2,22 & 0,13 & 0,00 & 0,06 \\
\hline 10 & Duampanua & 1,43 & 3,00 & 0,44 & 0,56 & 0,14 \\
\hline 11 & Batulappa & 0,27 & 5,70 & 0,00 & 1,16 & 0,00 \\
\hline 12 & Lembang & 0,52 & 3,93 & 1,62 & 1,98 & 1,29 \\
\hline \multicolumn{2}{|c|}{ Sub District LQ > 1} & 5 & 5 & 2 & 3 & 2 \\
\hline \multicolumn{2}{|c|}{ Sub District $L Q<1$} & 7 & 7 & 10 & 9 & 10 \\
\hline \multicolumn{2}{|r|}{ Rank } & 1 & 1 & 3 & 2 & 3 \\
\hline
\end{tabular}

Source: Secondary Data Processed, 2018 
for coffee commodities with an LQ value of 5.13. In addition, the base sector area for cocoa commodities is in the Districts of Patampanua, Duampanua, Batulappa, and Lembang. Pinrang is known as one of the centers of plantation production, especially cocoa and coffee. Based on the LQ results show that the plantation subsector has a competitive advantage. The greater the ability of the sector to meet its own regional needs and the greater the capacity of commodity exports due to the higher LQ value of the sector in a region.

The results of the $L Q$ analysis show that although the coffee commodity only has one base area, namely the Lembang Subdistrict area, the product has become a regional superiority and has even been able to attract investors from outside Indonesia. This is in accordance with the findings of Sitanggang and Sembiring (2013), that the opportunity to develop coffee as a driver of the regional economy is actually very large, especially for coffee production centers. This opportunity is getting bigger and wide open especially after the pioneering of the concept of Agropolitan Area in several rural areas in Indonesia. The results of this study are also supported by Simamora (2013) that the agricultural sector of Humbang Hasundutan District, namely food crops, plantations, livestock, and forestry subsectors is in the advanced but depressed classification. The results of the $L Q$ analysis of the plantation subsector also showed that coffee commodities were the basis in 7 sub-districts.

\section{CONCLUSION}

The leading commodities in the food crops and plantation subsector in Pinrang District are wetland paddy, maize, peanuts, soya beans, green beans, coconut, coffee, and cocoa spread in several sub-districts as follows: (1) wetland paddy in Mattiro Bulu, Patampanua, Cempa, Duampanua and Tiroang Subdistricts; (2) Maize in Patampanua, Cempa, Duampanua, Batulappa and Lembang Subdistricts; (3) Peanuts in Suppa and Lembang Subdistricts; (4) Soya beans in Suppa,

Table 3

Results of Location Quontient (LQ) Commodity Base in Plantation Sub-Sector in Subdistrict 2013-2017

\begin{tabular}{clccc}
\hline \multirow{2}{*}{ Number } & \multirow{2}{*}{ Subdistrict } & \multicolumn{3}{c}{ Plantation Subsector } \\
\cline { 3 - 5 } & Suppa & 0,95 & Coconut & Cocoa \\
\hline 1 & Mattiro Sompe & 0,36 & 0 & 0,08 \\
2 & 0,55 & 0 & 0,14 \\
3 & Lanrisang & 1,15 & 0 & 0,31 \\
4 & Mattiro Bulu & 0,15 & 0 & 0,45 \\
5 & Watang Sawitto & 1,01 & 0 & 0,08 \\
6 & Paleteang & 0,91 & 0 & 0,67 \\
7 & Tiroang & 1,39 & 0 & 0,72 \\
8 & Patampanua & 0,49 & 0 & 1,22 \\
9 & Cempa & 0,76 & 0,04 & 0,22 \\
10 & Duampanua & 0,41 & 0,09 & 1,12 \\
11 & Batulappa & 1,63 & 5,13 & 2,17 \\
12 & Lembang & 4 & 1 & 3,95 \\
\hline Subdistrict LQ $>1$ & 8 & 11 & 4 \\
\hline Subdistrict LQ $<1$ & 1 & 2 & 1 \\
\hline Rank & & &
\end{tabular}

Source: Secondary Data Processed, 2018 
Batulappa and Lembang Subdistricts; (5) Green beans in Suppa and Lembang Subdistricts; (6) Coconut in Mattiro bulu, Patampanua and Paleteang Subdistricts; (7) Coffee in Lembang District and (7) Cocoa in Patampanua, Duampanua and Lembang Subdistricts. Therefore, the support of the Pinrang District governmentis needed in increasing agricultural production, especially in the construction of agricultural facilities and infrastructure, especially the agricultural products market and local agricultural processing plants as well as increasing human resources in agriculture developed by Pinrang District to make it better. To optimize agricultural production, the results of the LQ analysis are references to the Government of Pinrang District in order to build an area of agricultural development in twelve Subdistricts in Pinrang.

\section{REFERENCE}

Amalia, F. (2012). Determination of the Leading Sectors of the Economy of the Region of Bone Bolango with the Regulation of the Sector Establishing GRDP. Journal of Ethics, 11 (2), 196207.

Arsyad, Lincolin. (2005). Introduction to Regional Economic Development Planning (Second Edition). Yogyakarta: BPFE.

Aziz, I. A., Yantu \& Lamusa, A. (2015). The Role of the Agricultural Sector in the Economy of Morowali District. e-J. Agrotekbis, 3 (2). 212 - 221.

Central Bureau of Statistics. 2015. Pinrang District in the 2015 Pinrang District Figure.

Harinta, Y, W., Basuki, J, S., \& Sukaryani, S. (2018). Mapping and Agribusiness Development of Vegetable Leading Commodities in Karanganyar District. Agriekonomika, 7 (1), 37-45.
Hayati, M., Elfiana \& Martina. (2017). The Role of the Agricultural Sector in the Development of the Bireuen District in Aceh Province. S. Agriculture Journal, 1 (3), 213 - 222.

Hayati, N \& Nugroho, T. R. (2018). Coastal Agro-Industry Development Based on Leading Commodities of Fish Catches. Agrieconomics, 7 (1), 1-9 |

Juanda, B, R. 2016. Potential for Increasing Rice Production by Increasing IP (Harvest Index) Through Application of Salibu Rice Technology. AGROSAMUDRA, Research Journal, 3 (1), 75-81.

Mangilaleng, E. J., Rotinsulu, D., \& Rompas, W. (2015). Analysis of the Leading Sector in South Minahasa District. Journal of Scientific Periodic Efficiency, 15 (04), 193-205.

Marpaung, I., Thamrin, T., \& Hutapea, Y. (2016). Increased rice productivity through improved production systems on tidal land in South Sumatra. Proceedings of the Suboptimal National Seminar, 479-487.

Masniadi, R., Suman, A., \& Sasongko. (2012). Agricultural Superior Commodity Analysis for Economic Development of Disadvantaged Regions in West Sumbawa District. Business-Economics, 03 (01), 5164.

Novita, K, A., Dewi, P \& Santoso, E, B. (2014). Leading Commodity Development in Food Crops Agriculture Sector in Karangasem District Through Agribusiness Approach. Journal of Engineering Pomits, 3 (2), 184-189.

Rasyid, A. (2016). Analysis of Potential Agriculture Sector Potential in Kediri District 2010-2014. Journal of Development Economics, 14 (2), 100-111. 
Ratag, J. P. D., Kapantow, G. H. M., \& Accounting, C. B. D. (2016). The Role of the Agriculture Sector in the Economy in South Minahasa District. AgriSosio Unsrat, 12 (2A), 239-250.

Sapriadi and Hasbiullah. (2015). Analysis of Determination of the Superior Economic Sector of Bulukumba District. Iqtisaduna, 1 (1), 71-86.

Simamora, A. P, Sirojuzilam and Supriadi. 2013. Analysis of the Potential of the Agricultural Sector for Regional Development in Humbang Hasundutan District. Economist Journal, 16 (2), 54-66.

Sitanggang, J \& Sembiring, S. A. (2013). Development of Coffee Potential as a Superior Commodity in the Dairi District Agropolitan Area. Journal of Economics and Finance, 1(6), 33-48.

Sjafrizal. (2008). Regional Economics Theory and Application. West Sumatra: Baduose Media Publisher.

Sukirno, S. (2004). Development Economics, Processes, Problems and Policies (Second Edition). Jakarta: Kencana Publisher Prenada Media Group.
Susilawati, Sastrawati, I and Wuna, S. 2016. Determination of the Main Commodities in the Food Crops Sector in Bone District, South Sulawesi. Proceedings of the 2016 IPLBI Scientific Meeting, 23-30

Watemin and Putri, R. H. (2016). Comparative Advantages of Holti-Cultural Commodities in Belik District's Agropolitan Area. Agrieconomics, 5(2), 170-176.

Wicaksono, I. A. (2011). Analysis of Location Quotient Sector and Agricultural Subsector in Districts in Purworejo District. Journal of Agricultural Sciences, 7(2), 11-18

Yolanda, H. M, Tarumun, S and Eliza. (2014). Effects of Plantation Subsectors on Economic Growth in Kampar District. Jom Faperta, 1(2), 1-15. 